Jurnal Geliga Sains 7(1), 1-10, 2019

(c) Program Studi Pendidikan Fisika FKIP Universitas Riau

ISSN 1978-502X; e-ISSN 2614-5383

\title{
DEVELOPMENT OF TEST INSTRUMENTS BASED ON SCIENCE LITERATION IN ENERGY MATERIALS IN LIFE SYSTEM
}

\author{
Nurul Elnica ${ }^{* 1)}$, Yennita ${ }^{2)}$, Muhammad Sahal ${ }^{3)}$ \\ ${ }^{1,2,3)}$ Physics Education, University of Riau \\ e-mail: nurul.elnica18@gmail.com \\ yennita@lecturer.unri.ac.id \\ muhammadsahal1012@yahoo.co.id
}

\begin{abstract}
Science literacy is the capacity of individuals to use scientific knowledge to be able to make the right decisions related to nature and human interaction. This study aims to produce test instruments based on scientific literacy on energy matter in living systems. The research method used is Research and Development $(R \& D)$ using the ADDIE (Analysis-Design-Development-Implemtation-Evaluation) development model. The stages of the study began with an analysis of the problems of science literacy skills of Indonesian students, then proceeded to develop indicators of questions based on the PISA 2015 indicators. After the indicators were developed, they were followed by making questions and question validation by 3 expert validators. Questions that have been validity tested are limited to 31 students. Data obtained from logical validity and limited trials. Then the data is analyzed descriptively. The results of the analysis of the data obtained are, the validation assessment of science literacy-based test instruments on energy material in living systems by experts is $79.39 \%$ with valid validity levels, while the assessment of limited trials is obtained from the validity of 17 questions declared valid and have value reliability of 0.6 with moderate reliability.
\end{abstract}

Keyword: development, test instruments, science literacy, energy in the life system.

\section{PENGEMBANGAN INSTRUMEN TES BERBASIS LITERASI SAINS PADA MATERI ENERGI DALAM SISTEM KEHIDUPAN}

\author{
Nurul Elnica ${ }^{1)}$, Yennita $^{2)}$, Muhammad Sahal $^{3)}$ \\ ${ }^{1,2,3)}$ Pendidikan Fisika, Universitas Riau
}

\begin{abstract}
Abstrak
Literasi sains adalah kapasitas individu dalam menggunakan pengetahuan ilmiah agar dapat membuat keputusan yang tepat yang berkaitan dengan alam dan interaksi manusia. Penelitian ini bertujuan untuk menghasilkan instrumen tes berbasis literasi sains pada materi energi dalam sistem kehidupan. Metode penelitian yang digunakan adalah Research and Development (R\&D) dengan menggunakan model pengembangan ADDIE (Analysis-Design-Development-Implemtation-Evaluation). Tahapan penelitian dimulai dari analisis permasalahan kemampuan literasi sains siswa Indonesia, lalu dilanjutkan dengan mengembangkan indikator soal yang didasarkan dari indikator PISA 2015. Setelah indikator dikembangkan dilanjutkan dengan pembuatan soal dan validasi soal oleh 3 validator ahli. Soal yang sudah valid diuji coba terbatas kepada 31 siswa. Data yang diperoleh

${ }^{* 1)}$ Komunikasi Penulis
\end{abstract}


dari validas logis dan uji coba terbatas. Kemudian data tersebut dilakukan analisis secara deskriptif. Hasil analisis data yang diperoleh yaitu, penilaian validasi instrumen tes berbasis literasi sains pada materi energi dalam sistem kehidupan oleh ahli adalah 79,39\% dengan tingkat validitas valid, sedangkan penilaian uji coba terbatas didapatkan hasil validitas butir soal yaitu 17 soal dinyatakan valid dan memiliki nilai reliabilitas sebesar 0,6 dengan tingkat reliabilitas sedang

Kata kunci: pengembangan, instrumen tes, literasi sains, energi dalam sistem kehidupan.

\section{Pendahuluan}

Menjalani abad 21 sampai saat ini, begitu banyak perubahan yang fundamental dalam berbagai aspek kehidupan manusia. Salah satu aspek kehidupan manusia yang harus mengalami perubahan besar adalah pendidikan. Perubahan mendasar diperlukan dalam cara kita berpikir tentang peran pendidikan dalam pembangunan global, karena itu memiliki dampak besar bagi kesejahteraan individu dan masa depan. Saat ini, pendidikan memiliki tanggung jawab untuk menghadapi tantangan dan aspirasi abad ke-21, dan menumbuhkan berbagai nilai dan keterampilan yang tepat yang akan mengarah pada pertumbuhan yang berkelanjutan dan inklusif, dan hidup damai bersama. Pendidikan dapat, dan harus, berkontribusi pada visi baru pembangunan global yang berkelanjutan (UNESCO, 2017).

Upaya dalam mencapai perubahan pendidikan secara global harus memperhatikan ketercapaian tujuan pendidikan nasional. Tujuan pendidikan dapat tercapai jika proses pembelajaran yang dilaksanakan dengan tepat. Proses pembelajaran yang dilaksanakan harus mengikuti fungsi dari pendidikan nasional yaitu, mengembangkan kemampuan dan membentuk watak serta peradaban bangsa bermartabat dalam rangka untuk mencerdaskan kehidupan bangsa, sehingga dapat mengembangkan potensi peserta didik agar menjadi manusia yang beriman dan bertakwa kepada Tuhan Yang Maha Esa, berakhlak mulia, sehat, berilmu, cakap, kreatif, mandiri, dan menjadi warganegara yang demokratis serta bertanggung jawab (Permendikbud, 2016).

Salah satu pembelajaran yang diterima oleh siswa adalah pembelajaran Ilmu Pengetahuan Alam (IPA). Berdasarkan paparan
Wakil Menteri Pendidikan dan Kebudayaan RI (Kemendikbud, 2014), materi yang disajikan pada IPA menuntut siswa berpikir kritis dan analitis sesuai dengan standar internasional. Pernyataan tersebut saat ini seharusnya mengarah pada proses kegiatan belajar untuk menghadapi era globalisasi, masalah lingkungan hidup, kemajuan teknologi informasi, konvergensi ilmu dan teknologi, ekonomi berbasis pengetahuan, serta pengaruh dan imbas teknologi berbasis sains. Semua pendapat yang telah diungkapkan mengacu kepada diperlukannya suatu kemampuan literasi sains sebagai hasil dari kegiatan pembelajaran dan pendidikan sains yang telah didapatkan siswa.

Kemampuan literasi sains dapat diartikan sebagai keterampilan seseorang untuk membedakan fakta-fakta sains dari bermacammacam informasi, mengenal dan menganalisis menggunakan metode penyelidikan saintifik serta kemampuan untuk mengorganisasi, menganalisis, menginterpretasikan data kuanti-tatif dan informasi sains (Gormally et al., 2012). PISA 2015 mendefinisikan literasi sains dalam tiga kompetensi yaitu: a) Menjelaskan fenomena secara ilmiah; b) Mengevaluasi dan merancang penyelidikan ilmiah; dan c) Menafsirkan data dan bukti secara ilmiah (OECD, 2016).

Sejalan dengan hal tersebut, pentingnya kemampuan literasi sains telah disadari oleh pemerintah Indonesia, dibuktikan dengan diterapkannya kurikulum 2013 revisi. Kurikulum 2013 revisi terdiri dari kompetensi inti yang teridiri dari 3 aspek, yaitu aspek sikap terdapat pada KI 1 dan 2, aspek pengetahuan pada KI 3 dan aspek keterampilan pada KI 4. Melihat komponen-komponen yang ada dalam model literasi sains oleh Graber dalam Jack Holrook \& Miia Rannikmae (2009), kompetensi inti dalam kurikulum 2013 revisi telah mengarah pada tercapainya literasi sains. 
Apabila kompetensi inti dipetakan berdasarkan model literasi sains Graber, maka KI 1 dan KI 2 masuk dalam komponen "whart people value", KI 3 masuk dalam komponen "what people know", dan KI 4 masuk dalam komponen "what people do". Maka dapat dikatakan bahwa kurikulum 2013 revisi yang telah diterapkan di Indonesia saat ini termasuk dalam kategori model literasi sains menurut Graber.

Keseriusan pemerintah dalam upaya meningkatkan kemampuan literasi sains siswa tidak hanya sebatas diterapkannya kurikulum 2013 revisi. Pemerintah juga turut menerapkan program gerakan literasi nasional. Dimana berdasarkan pedoman gerakan literasi nasional, terdapat enam literasi dasar yaitu literasi bahasa dan sastra, literasi numerasi atau literasi matematik, literasi sains, literasi finansial, literasi digital, dan literasi budaya dan kewarganegaraan (Kemendikbud, 2017).

Keberhasilan siswa dalam mempelajari literasi sains digambarkan melalui baik atau tidaknya nilai yang didapat siswa pada tes literasi dan peringkat Indonesia pada PISA. Namun kemampuan literasi sains siswa Indonesia masih pada level rendah. Hal ini dibuktikan dengan peringkat Indonesia pada PISA ditahun 2009 yaitu peringkat 61 dari 65 negara, tahun 2012 prestasi Indonesia kembali menurun yaitu menempati peringkat 64 dari 65 negara dan pada tahun 2015 peringkat Indonesia membaik meskipun hanya mampu menempati peringkat 62 dari 65 negara pada literasi sains yang diadakan oleh PISA (Kemendikbud, 2016).

Peringkat Indonesia pada PISA telah menunjukkan tentang kemampuan literasi sains yang masih rendah dan salah satu faktor yang menjadi penyebabnya, antara lain siswa belum terbiasa dalam menyelesaikan masalah yang berhubungan dengan keterampilan proses sains yang merupakan bagian utama literasi sains. Hal ini dibuktikan dengan penelitian yang dilakukan oleh Danny Ramadhan \& Wasis (2013) yang mem-bandingan level keterampilan proses sains dalam standar isi, soal UN, soal TIMMS dan soal PISA (literasi sains) secara berturut-turut $48 \%$, 78\%, 96\% dan 89\%. Hasil persentase tersebut didapatkan dari membandingkan 8 kemampuan proses sains yang ada pada soal standar isi, UN, soal PISA dan TIMSS. Delapan kemampuan proses sains tersebut meliputi, kemampuan mengamati, merumuskan hipotesis, merencanakan percobaan, melakukan percobaan, menginterpretasi data/grafik, meramal/ memprediksi, dimana kemampuan proses sains yang terukur dalam standar isi maupun ujian nasional masih relatif rendah dibandingkan dengan keterampilan proses sains dalam soalsoal yang diujikan di tingkat internasional. Penelitian yang sama juga menunjukkan level kognitif soal UN pada tingkat C4 dan C5 masih lebih rendah dibandingkan dengan soal PISA.

Berdasarkan pada hasil penelitian tersebut dapat dikatakan bahwa ada ketidak sesuaian antara apa yang diharapkan dengan keadaan sebenarnya yang terjadi di lapangan. Oleh karena itu, peneliti menganggap bahwa kemampuan literasi sains dan tes yang mengukurnya adalah objek yang perlu diteliti. Sehingga diperlukannya tes yang tidak hanya tepat untuk mengukur kemampuan literasi sains, tapi juga memiliki kualitas yang baik dan untuk menunjang dalam hal memvariasikan instrumen tes tersebut, sehingga kajian "pengembangan instrumen tes berbasis literasi sains pada materi energi dalam sistem kehidupan" ini menarik untuk dikaji.

\section{Bahan dan Metode}

Pengembangan instrumen tes berbasis literasi sains pada materi energi dalam sistem kehidupan dilaksanakan di SMPN 13 Pekan baru. Penelitian ini dilakukan pada bulan Januari 2019 sampai dengan bulan April 2019. Pada penelitian ini digunakan jenis penelitian dan pengembangan atau Research and Development (R\&D) yang menggunakan kerangka ADDIE (Sugiono, 2016). Tahap pengembangan perangkat percobaan disesuaikan dengan model ADDIE. Secara keseluruhan, kerangka berpikir penelitian ini dapat dilihat pada Gambar 1. 


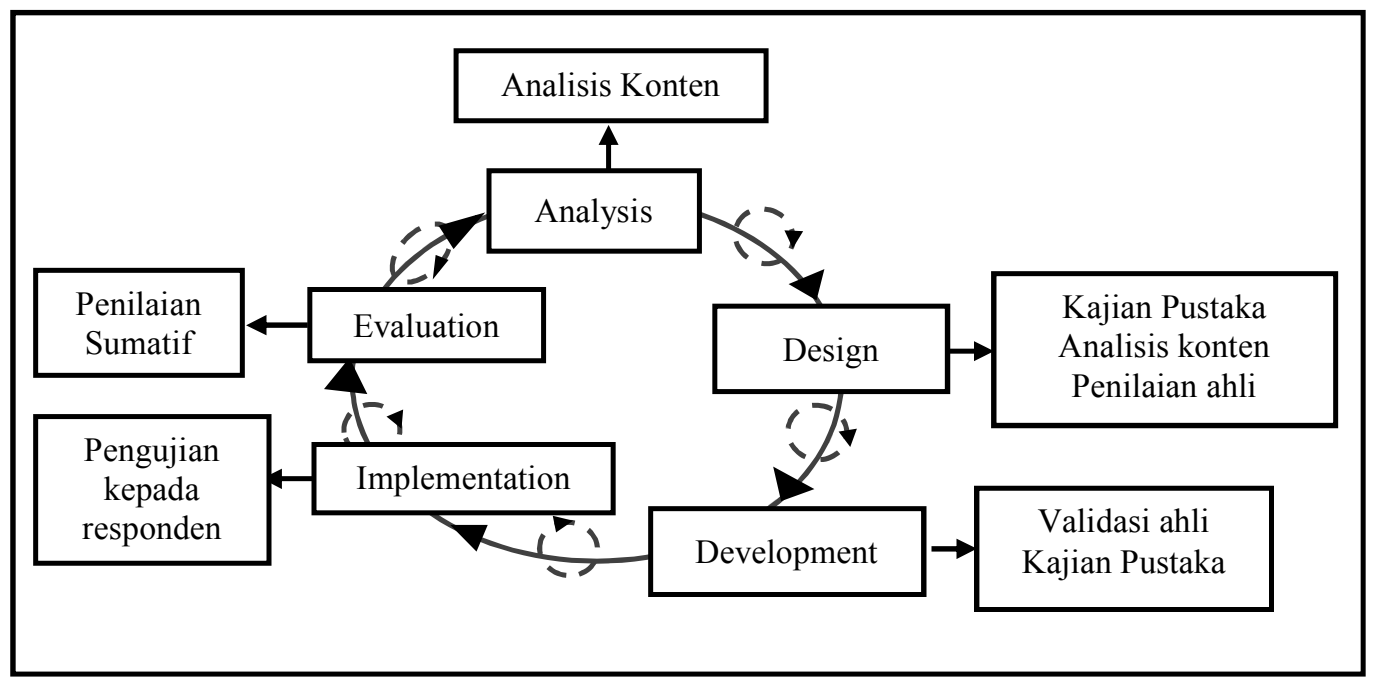

Gambar 1. Alur langkah ADDIE

Dimulai dari tahap analisis, dikumpulkan informasi tentang data literasi sains siswa Indonesia yang dikeluarkan oleh PISA, tujuan pendidikan nasional, dan karakteristik dari kurikulum 2013 untuk mengetahui kualitas sistem pendidikan dan siswa di Indonesia, serta keterkaitan antara literasi sains dengan kurikulum 2013. Hal tersebut untuk mengetahui kualitas sistem pendidikan dan siswa di Indonesia, serta keterkaitan antara literasi sains dengan kurikulum 2013.

Setelah tahap analisis dilanjutkan pada tahap desain yang dimulai mengumpulkan, menyusun, dan merancang produk yang akan dikembangkan (M. Rusdi, 2018). Pertama-tama sekali peneliti mengumpulkan indikatorindikator yang akan dijadikan pedoman pembuatan item soal, yaitu indikator dalam PISA 2015, kemudian menentukan proporsi setiap aspek untuk item soal, jenis item pertanyaan, dan waktu tes. Terakhir merancang format validasi dan item soal. Komponenkomponen yang harus dipersiapkan untuk membuat produk instrumen tes berbasis literasi sains pada materi energi dalam sistem kehidupan adalah mengembangkan indikator.

Pembuatan kelengkapan instrumen tes berbasis literasi sains ini dilanjutkan dengan tahap development atau pengembangan. Dalam tahapan pengembangan peneliti mulai melakukan validasi terhadap instrumen yang dikembangkan. Apabila menurut validator instrumen belum layak digunakan, maka akan direvisi untuk kemudian divalidasi kembali. Setelah instrumen dinyatakan valid, maka instrumen siap untuk diuji cobakan. Validator untuk menelaah kelayakan instrumen literasi sains fisika siswa dalam aspek konten, proses, dan konteks adalah dosen pendidikan Fisika FKIP UNRI. Jumlah validator tiga orang yang terdiri atas ahli materi dan ahli pembelajaran.

Proses analisis dilakukan dengan mengkonversi lembar validasi instrumen tes berbasis literasi sains menggunakan skala likert untuk memperoleh data kuantitatif. Alternatif jawaban diberi skor seperti pada Tabel 1.

Tabel 1. Kategori lembar penilaian validitas

\begin{tabular}{clc}
\hline No & \multicolumn{1}{c}{ Kategori } & Skor \\
\hline 1. & Sangat Sesuai & 5 \\
2. & Sesuai & 4 \\
3. & Kurang Sesuai & 3 \\
4. & Tidak Sesuai & 2 \\
5. & Sangat Tidak Sesuai & 1 \\
\hline
\end{tabular}

Sumber : (Sudaryono, 2018). 
Skor rata-rata yang diperoleh dikonversikan menjadi data kualitatif sesuai dengan kriteria penilaian seperti pada Tabel 2.

Tabel 2. Kategori interpretasi validitas instrumen tes

\begin{tabular}{ccl}
\hline No. & $\begin{array}{c}\text { Interval Skor } \\
(\%)\end{array}$ & Tingkat Validitas \\
\hline 1 & $80 \leq \mathrm{x} \leq 100$ & Sangat Valid \\
2 & $60 \leq \mathrm{x} \leq 79$ & Valid \\
3 & $40 \leq \mathrm{x} \leq 59$ & Cukup Valid \\
4 & $\mathrm{x} \leq 40$ & Tidak Valid \\
\hline
\end{tabular}

Sumber: (Sudaryono, 2018).

Setelah instrumen tes berbasis literasi sains dinyatakan valid oleh validator selanjutnya masuk ke tahapan selanjutnya yakni tahap Implementasi. Pada tahap implementasi akan dilakukan uji coba terbatas terhadap instrumen tes untuk melihat validitas butir soal dan reliabiliatas dari instrumen tes tersebut. Validitas butir soal instrumen tes ditujukan untuk mengetahui apakah instrumen tes dapat mengukur indikator yang diinginkan secara tepat. Setelah pengujian validitas butir soal dilakukan lalu akan dilakukan uji reliabilitas instrumen tes berbasis literasi sains untuk mendapatkan keabsahan dari instrumen yang dihasilkan. Instrumen tes diujicobakan kepada 31 siswa SMP kelas VII yang telah mempelajari materi energi dalam sistem kehidupan.

Proses analisis validitas butir soal dilakukan dengan mengkerolasikan antara butir soal dengan total, yang diperoleh dengan menggunakan rumus koefisien korelasi point biserial. Setelah mendapatkan nilai koefisien poin biserial, lalu nilai dibandingkan dengan $r$ tabel $(\mathrm{N}=31)$ yaitu 0,3009 dengan taraf keterpercayaan sebesar 0,05 sehingga didapatkan nilai validitas butir soal sesuai kategori validitas item, dimana soal yang valid memiliki nilai koefisien poin biserial lebih besar dibandingkan nilai $r$ tabel (Sudaryono, 2018).

Proses analisis reliabilitas instrumen tes dilakukan dengan menghitung nilai koefisien reliabilitas yang dihasilkan oleh instrumen tes. Perhitungan koefisien reliabilitas instrumen tes menggunakan rumus KR21. Setelah didapatkan nilai koefisien reliabilitas instrumen tes, langkah selanjutnya dengan menganalisis tingkat reliabiliatas dari instrumen tes sesuai dengan kriteria Tabel 3. .

Tabel 3. Kriteria reabilitas tes

\begin{tabular}{ccl}
\hline No & Reliabilitas & \multicolumn{1}{c}{ Interpretasi } \\
\hline 1 & $0,00<\mathrm{r}_{1} \leq 0,20$ & Sangat rendah \\
2 & $0,20<\mathrm{r}_{1} \leq 0,40$ & Rendah \\
3 & $0,40<\mathrm{r}_{1} \leq 0,60$ & Sedang \\
4 & $0,60<\mathrm{r}_{1} \leq 0,80$ & Tinggi \\
5 & $0,80<\mathrm{r}_{1} \leq 1,0$ & Sangat tinggi
\end{tabular}

Sumber: (Suhami Arikunto, 2012).

Instrumen tes berbasis literasi sains dalam penelitian ini dinyatakan valid apabila seluruh indikator pada instrumen validitas memiliki nilai rata-rata rentang $60 \%-80 \%$, jika terdapat salah satu dari indikator penilaian tersebut berada yang berada pada kategori tinggi atau sangat tinggi, selanjutnya instrumen tes dinyatakan valid secara butir soal apabila seluruh indikator pada instrumen tes memiliki nilai rata-rata $r_{p b i}>\mathrm{r}_{\text {tabel }}$ yang berada pada kategori valid dan instrumen tes dinyatakan reliabel apabila nilai koefisien reliabilitas minimal pada rentang $0,4-0,6$ yaitu pada kategori sedang.

Hasil akhir dari penelitian ini adalah instrumen tes berbasis literasi sains pada materi energi dalam sistem kehidupan yang terdiri dari cover instrumen tes, peraturan, soal literasi dan lembar jawaban siswa yang telah teruji valid dan reliabel untuk digunakan untuk mengukur kemampuan literasi sains siswa.

\section{Hasil dan Pembahasan}

Penelitian dan pengembangan instrumen tes berbasis literasi sains pada materi energi dalam sistem kehidupan ini berlangsung selama 4 bulan. Hasil penelitian pengembangan ini ialah tersusunnya seperangkat instrumen tes berbasis literasi sains pada materi energi dalam sistem kehidupan. Instrumen tes yang dikembangkan berupa soal-soal pilihan ganda berjumlah 20 soal, dimana melalui beberapa proses sebelum 
diujikan kepada siswa SMP kelas VII. Instrumen tes yang dikembangkan ditinjau oleh dosen pembimbing, kemudian divalidasi oleh 3 orang dosen Pendidikan Fisika Universitas Riau. Setelah instrumen tes telah dinyatakan valid, penelitian dilanjutkan dengan uji terbatas untuk mendapatkan validitas butir soal dan reliabilitas instrumen tes. Uraian yang akan dibahas pada bab ini merupakan hasil penelitian berdasarkan Research and Development yang telah dijelaskan sebelumnya.

\section{Analisis}

Tahap analisis merupakan tahap awal untuk menganalisis permasalahan yang terdapat dalam sistem pendidikan Indonesia khususnya pada kemampuan literasi siswa. Keberhasilan siswa dalam mempelajari literasi sains dapat dilihat dari baik atau tidaknya nilai yang didapat siswa pada tes literasi dan peringkat Indonesia pada PISA. Hanya saja kemampuan literasi sains siswa Indonesia masih pada level rendah. Hal ini dibuktikan dengan peringkat Indonesia pada PISA ditahun 2009 yaitu peringkat 61 dari 65 negara, tahun 2012 prestasi Indonesia kembali menurun yaitu menempati peringkat 64 dari 65 negara dan pada tahun 2015 peringkat Indonesia membaik meskipun hanya mampu menempati peringkat 62 dari 65 negara pada literasi sains yang diadakan oleh PISA (Kemendikbud, 2016).

Peringkat Indonesia pada PISA telah menunjukkan tentang kemampuan literasi sains yang masih rendah, dan salah satu faktor yang menjadi penyebab antara lain siswa belum terbiasa dalam menyelesaikan tes atau masalah yang berhubungan dengan keterampilan proses sains yang merupakan bagian utama literasi sains. Hal ini dibuktikan dengan penelitian yang dilakukan oleh Danny Ramadhan dan Wasis (2013) yang membandingan level keterampilan proses sains dalam standar isi, soal UN, Soal TIMMS dan soal PISA (literasi sains) secara berturut-turut $48 \%$, 78\%, 96\% dan $89 \%$. Hasil persentase tersebut didapatkan dari membandingkan Berdasarkan pada hasil penelitian tersebut dapat dikatakan bahwa ada ketidak sesuaian antara apa yang diharapkan dengan keadaan sebenarnya yang terjadi di lapangan. Berdasarkan informasi yang telah didapatkan, peneliti menyimpulkan bahwa instrumen tes berbasis literasi diperlukan, sehingga peneliti pun melakukan penelitian tentang pengembangan instrumen tes berbasis literasi sains pada materi energi dalam sistem kehidupan.

\section{Desain}

Perancangan instrumen tes berbasis literasi sains ini didasarkan oleh aspek yang ada pada PISA 2015. Peneliti mengambil tiga aspek yang ada pada PISA 2015 dan berhubungan dengan literasi sains yaitu, aspek: konteks, pengetahuan, dan kompetensi sains. Ketiga aspek tersebut dikembangkan indikator beserta sub indikatornya. Indikator dan sub indikator yang telah dikembangkan dilanjutkan dengan tahap pembuatan soal, kelengkapan instrumen seperti cover instrumen dan peraturan soal. Pemetaan pembagian soal untuk masing-masing aspek dapat dilihat pada Gambar 2, sedangkan desain cover instrumen beserta peraturan soal dapat dilihat pada Gambar 3(a), 3(b).

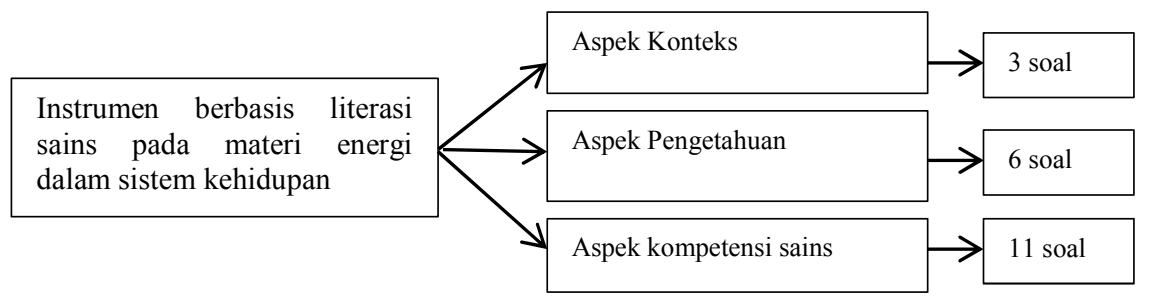

Gambar 2. Pemetaan pembagian soal. 


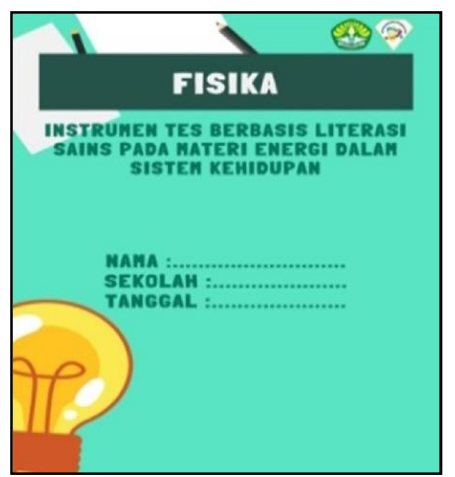

(a)

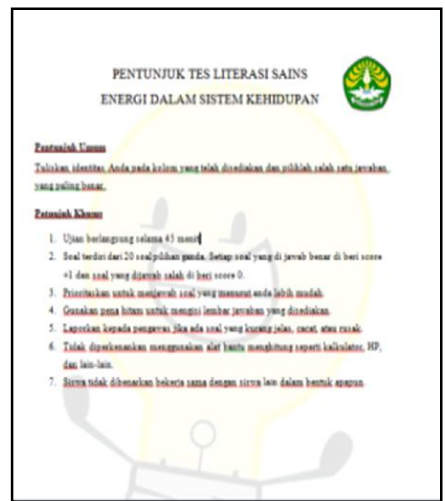

(b)

Gambar 3. (a) Cover instrumen, (b) Petunjuk pengerjaan tes

\section{Development (Pengembangan)}

Tahap pengembangan, dikembangkan indikator literasi sains yang berasal dari PISA 2015 menjadi indikator dan sub indikator. Sebelum mengembangkan soal berdasarkan indikator, peneliti mendiskusikan bersama tim peneliti terlebih dahulu proporsi soal yang akan dikembangkan dan hasil diskusi tersebut soal pada instrumen tes berbasis literasi sains ini disiapkan 20 soal. Soal telah dibuat diseleksi dulu bersama tim sebelum dilakukan validitas logis oleh tim ahli. Soal telah diseleksi kemudian direvisi terlebih dahulu kemudian dilanjutkan ke validator ahli.

Data diperoleh dari validasi terhadap instrumen tes yang dilakukan oleh 3 validator yaitu 3 orang validator ahli yang sudah memiliki pengalaman dibidangnya. Penilaian oleh validator dilakukan dengan menilai 4 aspek, yaitu aspek materi, literasi sains, konstruksi, dan tata bahasa. Data penilaian validator terhadap instrumen tes berbasis literasi sains pada materi energi dalam sistem kehidupan dapat dilihat pada Tabel 4 untuk aspek literasi sains, aspek materi, konstruksi, dan tata bahasa dalam bentuk persentase. Setelah seperangkat instrumen tes selesai dibuat dilanjutkan dengan validitas logis. Berdasarkan hasil penilaian oleh tim ahli, instrumen tes secara keseluruhan diperoleh persentase skor rata-rata 79,39\% yaitu pada kategori valid. Meski begitu beberapa soal harus mendapatkan perbaikan sesuai saran yang diberikan validator.

Tabel 4. Persentase penilaian kualitas instrumen tes oleh validator ahli

\begin{tabular}{clcc}
\hline No & Aspek yang dinilai & \% Skor rata-rata & Kategori \\
\hline 1. & Materi & $77,78 \%$ & Valid \\
2. & Literasi sains & $82,00 \%$ & Sangat Valid \\
3. & Konstruksi & $80,00 \%$ & Sangat Valid \\
4. & Tata Bahasa & $77,78 \%$ & Valid \\
\hline & \% Rata-rata aspek & $79.39 \%$ & Valid \\
\hline
\end{tabular}




\section{Implementation (Implementasi)}

Setelah instrumen tes dinyatakan valid oleh validator, maka tahap selanjutnya adalah implementasi atau penerapan secara nyata instrumen yang telah dibuat. Tahapan ini dilakukan dengan tujuan untuk mengetahui validitas butir soal dan reliabilitas instrumen. Tahapan ini dinamakan uji coba kelompok kecil dengan melibatkan 31 siswa SMP kelas VII yang telah mempelajari materi energi. Adapun data yang didapatkan dari uji terbatas tersebut sebagai berikut:

\section{Validitas butir soal}

Tujuan validitas butir soal adalah untuk menentukan dapat tidaknya suatu soal tersebut membedakan kelompok dalam aspek yang diukur sesuai dengan perbedaan yang ada dalam kelompok itu. Instrumen tes yang dikembangkan adalah bentuk pilihan ganda, dimana teknik korelasi yang digunakan adalah korelasi poin biserial. Penggunaan teknik korelasi poin biserial dalam melakukan ujicoba validitas dikarenakan data dari penelitian ini berupa data dikotom. Data dikotom sebagai data yang didapatkan dalam dua bentuk yaitu kalau benar benilai 1 dan jika salah bernilai 0 . Hasil validitas butir soal dihitung dan dibandingkan dengan nilai r-tabel yaitu 0,3009. Adapun hasil validitas butir soal tersebut dapat dilihat pada Tabel 5 .

\section{Reliabilitas}

Salah satu syarat agar hasil ukur suatu tes dapat dipercaya, maka tes tersebut harus mempunyai reliabilitas yang memadai. Tujuan dilakukannya uji reliabilitas adalah untuk menentukan seberapa besar variabilitas yang terjadi akibat adanya kesalahan pengukuran dan seberapa besar variabilitas skor tes sebenarnya.

Tabel 5. Validitas butir soal menggunakan koefisien korelasi $r_{p b i}$

\begin{tabular}{cccccccc}
\hline $\begin{array}{c}\text { No. } \\
\text { Soal }\end{array}$ & $\mathbf{M}_{\mathbf{P}}$ & $\mathbf{M}_{\mathbf{t}}$ & $\mathbf{S D}_{\mathbf{t}}$ & $\mathbf{P}$ & $\mathbf{Q}$ & $\boldsymbol{r}_{\boldsymbol{p} \boldsymbol{b} \boldsymbol{i}}$ & Interpretasi \\
\hline 1. & 12,5 & 10,7 & 3,18 & 0,45 & 0,55 & 0,51 & Valid \\
2. & 11,9 & 10,7 & 3.18 & 0,42 & 0,58 & 0,32 & Valid \\
3 & 12,2 & 10,7 & 3.18 & 0,52 & 0,48 & 0,48 & Valid \\
4. & 10,1 & 10,7 & 3.18 & 0,74 & 0,26 & $-0,33$ & Invalid \\
5 & 12,1 & 10,7 & 3.18 & 0,58 & 0,42 & 0,50 & Valid \\
6. & 11,6 & 10,7 & 3.18 & 0,61 & 0,39 & 0,36 & Valid \\
7. & 11,8 & 10,7 & 3.18 & 0,48 & 0,52 & 0,33 & Valid \\
8. & 11,9 & 10,7 & 3.18 & 0,55 & 0,45 & 0,43 & Valid \\
9. & 12,5 & 10,7 & 3.18 & 0,52 & 0,48 & 0,58 & Valid \\
10. & 11,8 & 10,7 & 3.18 & 0,58 & 0,42 & 0,42 & Valid \\
11. & 11,5 & 10,7 & 3.18 & 0,61 & 0,39 & 0,302 & Valid \\
12. & 11,9 & 10,7 & 3.18 & 0,52 & 0,48 & 0,40 & Valid \\
13. & 10,8 & 10,7 & 3.18 & 0,61 & 0,39 & 0,03 & Valid \\
14. & 11,9 & 10,7 & 3.18 & 0,65 & 0,35 & 0,50 & Valid \\
15. & 12,2 & 10,7 & 3.18 & 0,45 & 0,55 & 0,43 & Valid \\
16. & 12,2 & 10,7 & 3.18 & 0,35 & 0,65 & 0,34 & Valid \\
17. & 12,2 & 10,7 & 3.18 & 0,45 & 0,55 & 0,43 & Invalid \\
18. & 11,7 & 10,7 & 3.18 & 0,55 & 0,45 & 0,34 & Valid \\
\hline 19. & 10,1 & 10,7 & 3.18 & 0,52 & 0,48 & $-0,20$ & 0,55 \\
20. & 12,3 & 10,7 & 3.18 & 0,55 & 0,45 & &
\end{tabular}


Reliabilitas diperoleh dari satu kali pengujian. Untuk mendapatkan nilai reliabilitas dari instrumen yang dikembangkan, bisa menggunakan formula KR21. Uji reliabilitas dilakukan setelah uji validitas butir soal dilakukan, sehingga berdasarkan hasil uji validitas butir soal terdapat 3 soal yang tidak valid dan soal tersebut dibuang.

Hasil penelitian pengembangan instrumen tes berbasis literasi sains pada materi energi dalam sistem kehidupan ini, sudah dapat dikategorikan layak digunakan dikarenakan hasil uji coba reliabilitas berada pada kategori sedang yaitu 0,6 .

3. Kemampuan literasi siswa pada uji terbatas

Uji terbatas yang dilakukan tidak hanya mendapatkan hasil validitas butir soal dan reliabilitas dari instrumen saja, tetapi juga bisa melihat kemampuan literasi sains siswa. Dimana pada kemampuan literasi sains siswa dapat dilihat dari 3 aspek yaitu, aspek konteks, aspek pengetahuan dan aspek keterampilan sains. Hasil dari kemampuan literasi sains dapat dilihat pada Gambar 4.

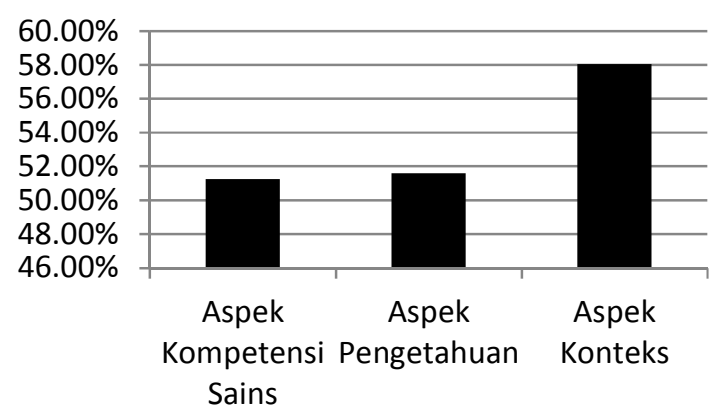

Gambar 4. Kemampuan literasi sains siswa pada uji terbatas.

Gambar 4 menunjukkan bahwa kemampuan awal literasi sains siswa secara keseluruhan adalah 52,98\%. Adapun kemampuan literasi sains tertinggi adalah pada aspek konteks.

\section{Evaluation (Evaluasi)}

Tahap akhir dari pengembangan dengan model ADDIE yaitu bagian Evaluasi. Evaluasi adalah proses untuk melihat apakah sistem pembelajaran yang sedang dibangun berhasil, sesuai harapan atau tidak. Begitupun dengan tahap evaluasi pada penelitian ini, ditujukan untuk mengetahui sejauh mana keberhasilan dari penelitian yang dilakukan. Misalnya pada tahap rancangan penelitian yang telah dilakukan terdapat perubahan atau revisi yang dilakukan untuk menyempurnakan produk yang dihasilkan.

\section{Simpulan dan Rekomendasi}

Instrumen tes berbasis literasi sains pada materi energi dalam sistem kehidupan telah berhasil dikembangkan dengan mengikuti tahap ADDIE. Hasil perolehan skor validasi instrumen tes berbasis literasi pada materi energi dalam sistem kehidupan secara keseluruhan dinyatakan valid dan reliabel. Sehingga instrumen tes berbasis literasi sains dapat digunakan untuk mengukur kemampuan literasi sains siswa.

Penelitian yang telah dilakukan ini, hanya terbatas pada perancangan, pembuatan instrumen tes, pengujian validitas butir soal, dan reliabilitas dari instrumen tes yang telah dibuat. Diharapkan instrumen tes yang dihasilkan dapat digunakan untuk mengukur serta menganalisis kemampuan literasi sains siswa dalam skala yang lebih besar.

\section{Daftar Pustaka}

Danny Ramadhan \& Wasis, 2013. Analisis Perbandingan Level Kognitif Dan Keterampilan Proses Sains dalam Standar Isi (SI), soal Ujian Nasional (UN), soal (Trends in International Mathematics and Science Study (TIMSS), dan soal Programme for International Student Assessment (PISA). Jurnal Inovasi Pendidikan Fisika. Vol. 02 No. 01 Tahun 2013, hlm. $20-25$.

Gormally, C., Brickman, P. \& Lutz, M., 2012. Developing a Test of Scientific Literacy Skills (TOLS): Measuring Undergraduates Evaluatio of Scientific Information Arguments. CBE-Life Science Education. 11, hlm. 364-377.

Jack Holbrook \& Miia Rannikmae, 2009. The Meaning of Scientific Literacy. Inter- 
national Journal of Environmental \& Science Education, Vol. 4, No. 3 hlm. 275-278.

Kemendikbud, 2014. Paparan Wakil Menteri Pendidikan dan Kebudayaan RI Bidang Pendidikan pada Konsep dan Implementasi Kurikulum 2013. (Online), https://www.kemdikbud.go.id/kemdikbud/ dokumen/Paparan/Paparan\%20Wamendik .pdf (diakses: 2 Januari 2019).

Kemendikbud, 2016. Peringkat dan Capaian PISA Indonesia Mengalami Peningkatan. (Online).

https://www.kemdikbud.go.id/main/blog/2 016/12/peringkat-dan-capaian-pisa-indone sia-mengalami-peningkatan (diakses : 20 Desember 2018).
Kemendikbud, 2017. Pengantar Diskusi Penyusun Pedoman dan Materi Gerakan Literasi Nasional untuk Guru. Kemendikbud RI, Jakarta.

M. Rusdi, 2018. Penelitian Desain dan Pengembangan Kependidikan. Rajawali Pres, Depok.

OECD, 2016. PISA 2015 Draft Science Framework. OECD Publishing, Paris.

Sudaryono, 2018. Metodologi Penelitian. Cetakan ke 2, Rajawali Pers, Jakarta.

Sugiyono, 2016. Metode Penelitian Pendidikan. Alfabeta, Bandung.

Suhami Arikunto, 2012. Dasar- Dasar Evaluasi Pendidikan Edisi 2. Bumi Aksara, Jakarta.

UNESCO, 2017. Education for Sustainable Development Goals Learning Objectives. United Nations Educational, Paris. 